\title{
KONSTRUKSI WACANA CITRA KEPEMIMPINAN JOKO \\ WIDODO DALAM PENANGANAN COVID-19 PADA INFOGRAFIS CNBC INDONESIA
}

\author{
Oleh
}

\author{
Dede Suprayitno \\ Universitas Paramadina, Jl. Gatot Subroto No. Kav. 97, RT. 4/ RW. 4, Kec \\ Mampang Prapatan, Jakarta Selatan, DKI Jakarta, 12790 \\ habibi.ds@gmail.com
}

\begin{abstract}
President Joko Widodo's leadership figure was increasingly tested during the corona virus disease 2019 pandemic (Covid-19). In fact, the corona virus has caused a multidimensional crisis. Not only did it hit the health sector, this crisis also put pressure on the economy and society. Therefore, strong leadership is needed to mobilize the forces to survive in difficult times. The steps taken by President Joko Widodo determine the fate of 270 million Indonesians. No wonder that every step taken is recorded in both print and electronic media. One of them is the construction of the president's image recorded through graphic information (infographics). Through infographic platforms, data becomes easier to digest. With the combination of written text and images, information becomes more interesting. Infographics are also able to give meaning through a series of signs formed in the design. This research aims to explore the construction of President Joko Widodo's leadership image in handling the Covid-19 pandemic, which is framed in infographics. This study uses a qualitative approach and research methods Norman Fairclough's critical discourse analysis is descriptive. Namely by taking an example of the practice of infographic production in the media of $C N B C$ Indonesia. The infographic data is taken from the period March to June 2020. The results of this study describe the form of discourse construction of President Joko Widodo's image in the CNBC infographic text of Indonesia. The president is described as being responsive in handling the Covid-19 pandemic.
\end{abstract}

Key Words: Leadership, Joko Widodo, Covid-19, Infographics, CNBC Indonesia 
KONSTRUKSI WACANA CITRA KEPEMIMPINAN JOKO WIDODO

DALAM PENANGANAN COVID-19 PADA INFOGRAFIS CNBC

INDONESIA

PENDAHULUAN

Awal 2020 dunia digegerkan

oleh kemunculan virus corona.

Kehadiran penyakit ini, memicu

kekhawatiran banyak negara. Kepala

negara berdiskusi mencari jalan

keluar untuk keluar dari krisis yang

kian parah. Ancaman ekonomi resesi,

hingga krisis multidimensi

membayangi banyak negara. Langkah

pemimpin negara sangat menentukan

keberhasilan suatu negara bertahan

dari serangan pandemi Covid-19.

Termasuk diantaranya adalah Indonesia.

Di Indonesia, penyebaran virus corona pertama kali dilaporkan pada 2

Maret 2020. Virus itu menulari 2

warga negara Indonesia (WNI).

Pemerintah yang sebelumnya menyangkal adanya penularan virus, kini terpatahkan. Penyebaran virus corona kian masif. Pemerintah Indonesia menerapkan kebijakan
Pembatasan Sosial Berskala Besar (PSBB) untuk mencegah penyebaran virus.

Presiden Joko Widodo pun banyak mengambil langkah-langkah strategis dalam menangani pandemi Covid-19. Bersama menteri yang tergabung dalam Kabinet Indonesia Maju, Joko Widodo mengurai permasalahan yang timbul akibat Covid-19. Baik itu dengan kebijakan stimulus pelonggaran ekonomi, maupun perang langsung melawan Covid-19. Meski demikian, tak jarang pula kritik dan saran membanjiri langkah Joko Widodo. Berbagai langkah yang diambil saat masa pandemi itu, terekam dengan baik melalui media cetak maupun elektronik.

Berbagai bentuk pemberitaan pun membanjiri masyarakat. Baik itu yang berbentuk cetak, elektronik, audio, maupun audio visual. Di era 
KONSTRUKSI WACANA CITRA KEPEMIMPINAN JOKO WIDODO

DALAM PENANGANAN COVID-19 PADA INFOGRAFIS CNBC

INDONESIA

digital saat ini, arus informasi Infografis juga memiliki ruang menjadi kian banyak. Jurnalisme khusus, untuk menggantikan pesanonline pun berkembang dengan pesan padat informasi, melalui sangat pesat, seiring dengan penetrasi gambaran visual yang lebih mudah internet dan kian majunya device dipahami.

sebagai alat penunjang komunikasi.

Berdasarkan latar belakang Hal ini kian mendorong produksi masalah tersebut, rumusan masalah konten berita, dapat dilakukan dengan penelitian ini antara lain: seperti apa lebih kreatif, cepat, dan gambaran produksi pesan infografis multiplatform.

yang dilakukan CNBC Indonesia?

Pada era jurnalisme online saat Khususnya mengenai sosok Presiden ini, konten infografis (informasi Joko Widodo dalam penanganan grafis) kian berkembang dan menjadi Covid-19. Lalu konstruksi wacana salah satu elemen penting dalam apa saja yang tersaji dalam teks proses produksi berita. Infografis infografis CNBC Indonesia terkait dalam jurnalisme online memiliki kebijakan pemerintah menangani ruang khusus yang diproduksi secara pandemi?

teratur. Seiring dengan isu yang sedang berkembang hangat.

Misalnya saja yang dilakukan infografis yang dilakukan CNBC CNBC Indonesia, media yang berada Indonesia. Khususnya mengenai di bawah naungan Grup Transmedia sosok Presiden Joko Widodo. Selain ini, secara teratur memproduksi itu juga untuk mengupas konstruksi infografis dalam portal berita digital. wacana apa saja yang diproduksi 
KONSTRUKSI WACANA CITRA KEPEMIMPINAN JOKO WIDODO

DALAM PENANGANAN COVID-19 PADA INFOGRAFIS CNBC

INDONESIA

dalam infografis, terkait kebijakan

pemerintah dalam menangani

pandemi Covid-19.

\section{METODE PENELITIAN}

Penelitian ini menggunakan pendekatan kualitatif. Yakni metode untuk mengeksplorasi dan memahami makna —oleh sejumlah individu atau sekelompok orang — dianggap berasal dari masalah sosial atau kemanusiaan. Proses penelitian kualitatif melibatkan upaya-upaya penting, seperti mengajukan pertanyaan- pertanyaan atau prosedur-prosedur, mengumpulkan data yang spesifik dari para partisipan, menganalisis data secara induktif mulai dari tema-tema yang khusus, ke tema-tema umum dan menafsirkan makna data (Creswell, 2010). Penelitian kualitatif didasarkan konteks lokal tempat fenomena berlangsung, generalisasi hasil penelitian terhadap populasi yang lebih besar/ situasi lain menjadi problematik (Lee dalam Mulyana,
2013).

Sedangkan jenis penelitian ini merupakan deskriptif. Yakni bertujuan membuat deskripsi secara sistematis, faktual, dan akurat tentang fakta- fakta dan sifat-sifat populasi atau objek tertentu (Kriyantono, 2014). Tujuan dari penelitian deskriptif yakni mengembangkan konsep dan menghimpun fakta-fakta, bukan menguji hipotesis. Penelitian deskriptif berusaha menemukan pola sederhana yang didasarkan pada konsep tertentu (Bajari, 2015).

$$
\text { Penelitian ini mengupas }
$$
konstruksi teks yang terjadi dalam produksi konten infografis $\mathrm{CNBC}$ Indonesia. Topik yang dianalisis mengenai peran Presiden Joko Widodo dalam menangani pandemi Covid-19. Pasalnya, besarnya peristiwa pandemi yang dihadapi, membuat pemerintah melakukan langkah-langkah extraordinary (luar 
KONSTRUKSI WACANA CITRA KEPEMIMPINAN JOKO WIDODO

DALAM PENANGANAN COVID-19 PADA INFOGRAFIS CNBC

INDONESIA

biasa) (CNBC Indonesia, 2020). merelaksasi kebijakan Pembatasan

Dalam kondisi ini pemerintah Sosial Berskala Besar (PSBB).

melalukan berbagai upaya luar biasa, Pada rentang waktu tersebut, untuk menuntaskan penyebaran virus pemerintah banyak melakukan corona. Metode analisis data yang berbagai jurus kebijakan untuk digunakan dalam penelitian ini, meminimalkan dampak negatif menggunakan pisau analisis wacana pandemi Covid-19. Hal ini juga turut kritis milik Norman Fairclough. terekam dengan baik dalam konten Diantaranya terbagi dalam tiga tahap produksi media. Oleh karena itu, analisis, yakni deskripsi, interpretasi, sumber primer dalam penelitian ini dan eksplanasi.

yakni teks infografis yang diproduksi

Penelitian ini mengambil CNBC Indonesia. Selain itu, sumber rentang waktu produksi infografis sekunder dalam penelitian ini yakni pada periode Maret hingga Juni 2020. hasil wawancara dengan Edward Periode ini dipilih karena pada 2 Ricardo, ilustrator CNBC Indonesia. Maret 2020 merupakan waktu Wawancara dilakukan di kantor pertama kali Indonesia melaporkan CNBC Indonesia di gedung kasus corona. Sehingga pemerintah Transmedia Lt. 3A J1. Kapten P. Indonesia semakin fokus untuk Tendean, Mampang Prapatan, Jakarta menuntaskan persoalan akibat Selatan.

pandemi Covid-19. Sementara Pemilihan narasumber yang penelitian dibatasi selama satu dilakukan penulis, menggunakan caturwulan, yakni hingga Juni 2020. prosedur purposif. Bungin (2011) Pada periode ini, pemerintah mulai menyebut prosedur purposif 
KONSTRUKSI WACANA CITRA KEPEMIMPINAN JOKO WIDODO

DALAM PENANGANAN COVID-19 PADA INFOGRAFIS CNBC

INDONESIA

dilakukan dengan menentukan yang jauh, selain itu juga mampu

kelompok peserta yang menjadi menyampaikan informasi dengan

informan sesuai dengan kriteria informasi yang detail.

terpilih yang relevan dengan masalah "This dynamism can be readily

penelitian tertentu. Pemilihan

narasumber dilakukan dengan

pertimbangan: (1) memproduksi

konten infografis secara langsung; (2)

mengetahui alur produksi konten

infografis: (3) memiliki pengalaman

yang baik mengenai produksi konten

infografis.

\section{TINJAUAN PUSTAKA}

\section{Komunikasi Massa}

Bentuk komunikasi massa saat ini telah berkembang dengan sangat pesat. Perubahan yang sangat dinamis ini ditunjang oleh berkembangnya teknologi yang ada di masyarakat. Media massa dapat menjangkau objek komunikasi secara lebih luas. Hal didukung oleh berkembangnya teknologi, sehingga informasi bisa disampaikan dengan tujuan jarak 
KONSTRUKSI WACANA CITRA KEPEMIMPINAN JOKO WIDODO

DALAM PENANGANAN COVID-19 PADA INFOGRAFIS CNBC

INDONESIA

proses komunikasi massa, teks, discourse practice, dan

memerlukan keterampilan khusus. sociocultural practice. Fairclough

Diantaranya seperti kemampuan melibatkan faktor koherensi dan

melek huruf, penggunaan teknologi, kohesivitas, guna menjelaskan

serta memahami secara kontekstual. bagaimana antarkata atau kalimat

2. Analisis Wacana Kritis tersebut digabung sehingga

Norman Fairclough membentuk pengertian. Ketiga

Analisis wacana kritis menurut elemen tersebut, dapat digunakan

Fairclough memandang bahwa bahasa untuk menganalisis dan melihat

adalah bagian yang tidak dapat ideasional, relasi, dan identitas.

direduksi dalam kehidupan sosial, Fairclough berpendapat bahwa

secara dialektik saling berhubungan teks dapat dilihat sebagai sebuah

dengan unsur-unsur lain kehidupan tingkatan. Teks yang bertebaran,

sosial, sehingga analisis sosial dan bukan hanya menampilkan bagaimana

penelitian selalu harus suatu objek digambarkan, namun juga

mempertimbangkan bahasa dapat menjelaskan hubungan antara

(Fairclough dalam Gasa, 2019). objek yang dijelaskan. Fairclough

Fairclough berupaya mengurai bahwa setiap teks pada

mengungkap pola ideologis dan dasarnya dapat diuraikan dan dianlisis

kekuatan dalam teks dalam metode dengan tiga unsur, yakni representasi,

analisis penelitiannya (Rahimi \& relasi dan identitas. (Eriyanto, 2012).

Riasati, dalam Gasa, 2019). Pendekatan Fairclough dalam

Fairclough membagi analisis wacana menganalisa teks dianggap lengkap

dalam tiga bentuk dimensi, yaitu: karena berusaha menyatukan tiga 
KONSTRUKSI WACANA CITRA KEPEMIMPINAN JOKO WIDODO

DALAM PENANGANAN COVID-19 PADA INFOGRAFIS CNBC

INDONESIA

tradisi yaitu (Annas, 2018). dengan menggunakan berbagai

Diantaranya, pertama dimensi elemen seperti gambar, ilustrasi,

Tekstual (Mikrostruktural), meliputi: tipografi, peta dan visualisasi (Dur, representasi, relasi, dan identitas. 2014). Tujuan dari infografis terbagi Kedua, dimensi Praktik Produksi menjadi tiga kategori, yakni untuk Teks (Meso-struktural), meliputi: menginformasikan, menghibur dan produksi teks, penyebaran teks dan mempersuasi audiens sehingga konsumsi teks. Ketiga, dimensi audiens memberikan perhatian, Praktik Sosial Budaya menyempatkan untuk membaca, (Makrostruktural), meliputi: menyimpulkan dan melakukan aksi situasional, institusional dan sosial. sesuai apa yang ada di dalam

\section{Infografis}

Infografis berasal dari kata infographics dalam bahasa Inggris yang merupakan singkatan dari information dan graphics adalah bentuk visualisasi data yang menyampaikan informasi kompleks kepada pembaca agar dapat dipahami dengan lebih mudah dan cepat. (Saptodewo, 2014). Infografis mencakup presentasi visual yang dapat menjelaskan rangkaian cerita atau proses dari serangkaian data infografis (Krum, 2013).

Infografis sering disebut pula sebagai ilustrasi informasi (Glasgow, dalam Wicandra, 2006). Infografis yang awalnya dikenal lewat media cetak, kini telah merambah dunia digital. Bahkan bentuknya kini menjadi lebih dinamis dan mudah dibagikan lewat berbagai platform media digital. Sebelumnya, Wicandra (2006) menggambarkan infografis umum ditampilkan dalam ruang tertentu di surat kabar. Infografis 
KONSTRUKSI WACANA CITRA KEPEMIMPINAN JOKO WIDODO

DALAM PENANGANAN COVID-19 PADA INFOGRAFIS CNBC

INDONESIA

digambarkan menjadi jembatan,

untuk memberikan informasi naratif yang cenderung padat dan berat.

Pada media cetak, infografis juga umum ditayangkan dalam bentuk grafik batang, garis, maupun lingkaran. Di era digital saat ini pun, penampilan grafik tersebut juga masih umum ditemui. Pada dasarnya, infografis terbagi menjadi dua jenis, yakni infografis informatif dan grafis visual. Wicandra (2006) menjelaskan grafis informatif adalah grafis yang memaparkan kejadian, proses, hasil penelitian maupun fakta secara artistik. Sementara grafis visual adalah grafis ilustrasi dari seluruh isi berita maupun opini yang digambarkan secara analogi, simbol dan metafora dengan artistik.

Kurniasih (2016) menyebut setidaknya ada tiga elemen infografis, yakni: Pertama, material berupa data, informasi atau pengetahuan yang akan menjadi materi atau isi dalam

infografis. Tanpa materi berupa data, informasi atau pengetahuan, infografis tidak akan bisa dibuat. Kedua, kreator berupa perangkat lunak (software) yang akan mendukung pembuatan sebuah infografis. Ketiga, elemen visual berupa koding warna, grafis dan ikon yang akan dipergunakan dalam infografis. Elemen visual ini harus sesuai dengan isi, tujuan dan target audien dari dibuatnya infografis ini.

Secara garis besar, ada empat jenis infografis. (Ramírez, dkk dalam Kurniasih, 2016). Diantaranya yakni infografis yang berdasarkan pada statistik (statistical based), infografis yang berdasarkan pada jadwal (timeline based), infografis yang berdasarkan pada proses (process based), dan infografis yang berdasarkan pada lokasi atau geografis. 
KONSTRUKSI WACANA CITRA KEPEMIMPINAN JOKO WIDODO

DALAM PENANGANAN COVID-19 PADA INFOGRAFIS CNBC

INDONESIA

Infografis tidak mempunyai data untuk menceritakan sebuah cerita

nilai ekonomis maupun pengaruh daripada menggunakan cerita yang yang terlalu menonjol dibandingkan justru merusak menenuhi presentasi bidang lain dalam desain komunikasi visual.

visual. Namun infografis begitu

penting dalam membantu masyarakat

mengerti, mereproduksi dan

merekonstruksi berita yang

dikonsumsinya. (Saptodewo, 2014).

Dalam studinya, Haan dkk

(2018) menyebutkan bahwa

visualisasi digunakan dalam berita,

namun tidak dilihat sebagai perangkat

penyampai informasi yang

independen. Penggunaannya pun

disesuaikan dengan minat konsumen

terhadapi topik berita tertentu dan

pertimbangan estetika. Teks dan

visualisasi harus saling berhubungan,

jika tidak akan membingungkan

pembaca. Yu dan L. Shi (2018)

menyebut representasi visual dari

informasi berita harus terstruktur,

dengan kata lain, dapat menggunakan

\section{HASIL DAN PEMBAHASAN}

Dalam mengumpulkan data peneliti menggunakan kata kunci Joko Widodo dan Covid-19. Kata kunci tersebut dicari dalam infografis CNBC Indonesia yang terbit pada Maret hingga Juni 2020. Pada pencarian tersebut, peneliti menemukan 8 infografis yang membahas langkah dan sikap Presiden Joko Widodo dalam menangani pandemi Covid-19, antara lain sebagai berikut:

\begin{tabular}{|l|c|}
\hline \multicolumn{1}{|c|}{ Judul } & Waktu Terbit \\
\hline $\begin{array}{l}\text { Tak Cuma Sekali, Tapi } \\
\text { Berkali-Kali Jokowi } \\
\text { Jengkel Ke Menteri }\end{array}$ & 6 Maret 2020 \\
\hline $\begin{array}{l}\text { Rupiah Tembus Di Atas } \\
16.000\end{array}$ & 21 Maret 2020 \\
\hline $\begin{array}{l}\text { Ini 6 Paket Bantuan } \\
\text { Jokowi }\end{array}$ & 31 Maret 2020 \\
\hline
\end{tabular}


KONSTRUKSI WACANA CITRA KEPEMIMPINAN JOKO WIDODO

DALAM PENANGANAN COVID-19 PADA INFOGRAFIS CNBC

INDONESIA

\begin{tabular}{|c|c|}
\hline $\begin{array}{l}\text { Gegara Covid-19, } \\
\text { Bahan Pangan } \\
\text { Indonesia Alami Defisit }\end{array}$ & 29 April 2020 \\
\hline $\begin{array}{l}\text { Jokowi Ogah Impor } \\
\text { Vaksin }\end{array}$ & 21 Mei 2020 \\
\hline $\begin{array}{l}\text { Lima Arahan Jokowi } \\
\text { Adaptasi "New } \\
\text { Normal" }\end{array}$ & 11 Juni 2020 \\
\hline $\begin{array}{l}\text { Jokowi Murka Ke Para } \\
\text { Menteri }\end{array}$ & 30 Juni 2020 \\
\hline $\begin{array}{l}\text { Arahan Presiden RI } \\
\text { Mengenai Percepatan } \\
\text { Penanganan Dampak } \\
\text { Pandemi Covid-19 }\end{array}$ & 30 Juni 2020 \\
\hline
\end{tabular}

Tabel 2. Materi Infografis

Pemberitaan Joko Widodo di Tengah

Pandemi Covid-19

\section{Analisis Mikrostruktur (teks)}

Representasi Anak Kalimat \&

\section{Gabungan Anak Kalimat}

Peneliti menemukan

penggunaan anak kalimat dalam judul

infografis, cenderung bersifat lugas

dan bermakna denotatif. Dimana

keseluruhan judul tidak menggunakan

gaya bahasa yang membutuhkan

waktu untuk menginterpretasinya.

Dengan basis media online, CNBC

Indonesia menggunakan judul-judul bersifat langsung. Selain itu, judul

dibuat semenarik mungkin, guna

menarik perhatian pembaca.

Misalnya saja pada infografis berjudul "Tak Cuma Sekali, Tapi Berkali-Kali Jokowi Jengkel Ke Menteri”. Judul ini ingin memberi makna penekanan kejengkelan Presiden Joko Widodo terhadap kinerja para menteri. Kemarahan presiden yang lebih dari sekali itu, juga sekaligus menjadi konsumsi publik. Ada dua pemaknaan yang bisa jadi pemaknaan alternatif. Pertama, marahnya ini bisa menjadi simbol kekecewaan yang berat sehingga publik juga perlu tahu dan menjadi hakim atas kinerja menteri. Asumsi yang kedua, Presiden Joko Widodo juga ingin mendapatkan perhatian rakyat, bahwa memimpin negara bukan pekerjaan mudah maka dia berulang kali mempublikasikan kejengkelannya. 
KONSTRUKSI WACANA CITRA KEPEMIMPINAN JOKO WIDODO

DALAM PENANGANAN COVID-19 PADA INFOGRAFIS CNBC

INDONESIA

Hal yang sama juga terjadi pada Joko Widodo bisa memutuskan

judul "Jokowi Murka Ke Para reshuffle pada menteri yang tidak

Menteri". Kata "murka" dalam dapat melaksanakan tugas dengan

Kamus Besar Bahasa Indonesia baik, bahkan sampai melakukan

(KBBI) bisa memiliki makna sangat pembubaran lembaga.

marah. Makna ini turut dipertegas

lewat desain karikatur Joko Widodo

yang menunjukkan raut muka

mengencang, sembari mengangkat

kedua tangan ingin meremas, sebagai
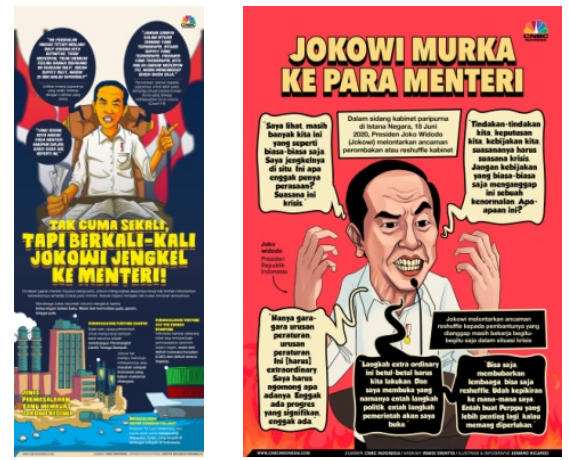

tanda kemarahan. Bila dikulik lebih

dalam, kemarahan Joko Widodo

Gambar 1 \& 2. Infografis CNBC

ditunjukkan dalam pilihan bahasa

Indonesia

Berikutnya judul infografis juga menyindir para menteri. Kalimat menunjukkan situasi berat yang marahnya pun cenderung panjangtengah dihadapi Indonesia. Hal ini panjang. Dalam penyampaiannya nampak dari infografis berjudul: secara visual, Joko Widodo "Rupiah Tembus Di Atas 16.000". menunjukkan kemarahan dengan Infografis ini dirilis pada bulan yang membaca teks, di atas podium, dan tidak meledak-ledak. Kemarahan sama, dimana Indonesia pertama kali melaporkan kasus infeksi virus Joko Widodo mirip seperti yang corona pada 2 Maret 2020. Kurang dilakukan Soeharto. Meski marah, dari 3 pekan sejak pengumuman tapi tetap tenang di atas podium. tersebut, mata uang rupiah terus Meskipun dalam penyampaiannya, melemah terhadap dolar Amerika 
KONSTRUKSI WACANA CITRA KEPEMIMPINAN JOKO WIDODO

DALAM PENANGANAN COVID-19 PADA INFOGRAFIS CNBC

INDONESIA

Serikat. Bukan hanya itu, bursa saham

Bukan hanya soal mata uang

dan komoditas juga turut jatuh. rupiah, pemerintah juga dihadapi

(CNBC Indonesia, 2020).

tantangan ketatnya bahan pangan di

Melemahnya mata uang rupiah Indonesia. Hal ini tersaji dalam dengan waktu yang singkat, bisa infografis berjudul: "Gegara Covidmenjadi preseden buruk bagi dunia 19, Bahan Pangan Indonesia Alami industri. Perubahan kurs yang Defisit". Pandemi Covid-19 membuat mendadak ini, akan berpengaruh bagi persediaan bahan pangan di Indonesia kinerja keuangan industri. Ada defisit. Dalam narasi teks infografis beberapa penyebab, yang membuat disebutkan bahwa hal tersebut rupiah kian melemah terhadap dolar diungkapkan Presiden Joko Widodo AS. Antara lain terjadinya capital dalam rapat terbatas bersama dengan outflow di pasar saham $\mathrm{Rp}$ 9,66 para menteri. Ada defisit terhadap triliun. Lalu penularan virus yang sejumlah komoditas di Indonesia. cepat sehingga pemerintah Diantaranya seperti beras (7 provinsi), mengambil kebijakan pembatasan jagung (11 provinsi), cabai besar (23 sosial. Penurunan aktivitas publik provinsi), cabai rawit (19 provinsi), tersebut juga turut berimbas pada bawang merah (1 provinsi), bawang kelesuan ekonomi. Hal ini tersaji putih (31 provinsi), minyak goreng dalam narasi teks yang terdapat dalam (34 provinsi), telur ayam infografis. Presiden Joko Widodo pun provinsi), dan gula pasir (30 mengambil perintah kepada Bank provinsi).

Indonesia untuk turut menjaga stabilitas rupiah. 


\section{KONSTRUKSI WACANA CITRA KEPEMIMPINAN JOKO WIDODO \\ DALAM PENANGANAN COVID-19 PADA INFOGRAFIS CNBC \\ INDONESIA}
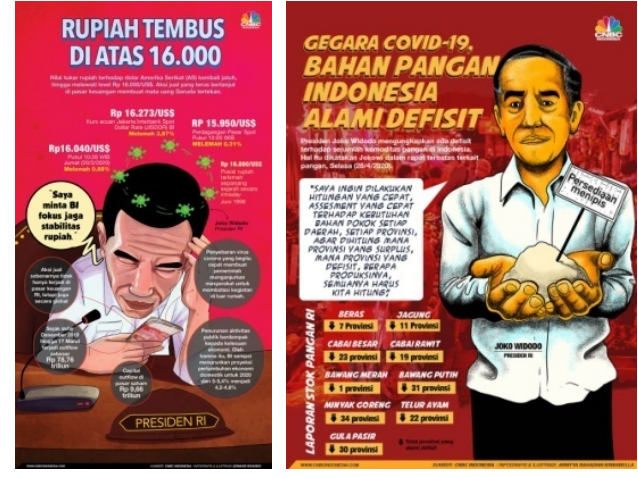

Gambar 3\&4. Infografis CNBC

\section{Indonesia}

Atas defisitnya bahan

komoditas pangan, Joko Widodo meminta dilakukan perhitungan cepat di setiap provinsi. Agar dapat diketahui, provinsi mana yang surplus dan provinsi yang defisit. Pemerataan produksi pangan ini menjadi salah satu instrumen penting ketahanan pangan di Indonesia. Di tengah situasi pandemi Covid-19 ini, Joko Widodo menginginkan adanya langkah cepat.

$$
\text { Presiden Joko Widodo juga }
$$
digambarkan sebagai sosok yang memegang kendali penuh atas penanganan pandemi Covid-19 di Indonesia. Hal ini nampak pada infografis berjudul: "Lima Arahan Jokowi Adaptasi "New Normal"' dan "Arahan Presiden RI Mengenai Percepatan Penanganan Dampak Pandemi Covid-19". Infografis ini dikeluarkan pada Juni 2020, dimana pada masa ini Indonesia mulai melakukan relaksasi pembatasan sosial berskala besar (PSBB). Relakasasi dilakukan dengan tetap mematuhi aturan protokol kesehatan yang sering disebut sebagai era new normal.
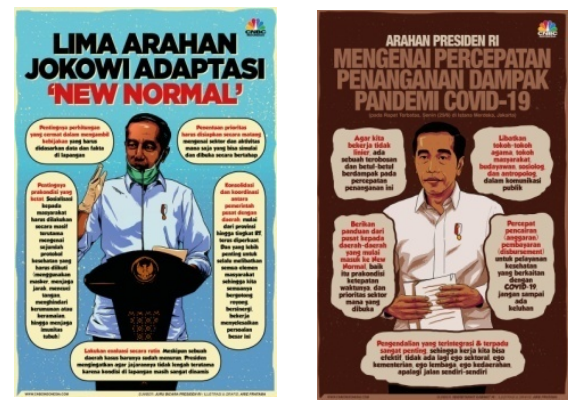

Gambar 5\&6. Infografis CNBC

Indonesia

Pada infografis "Lima Arahan Jokowi Adaptasi 'New Normal'", kalimat ini memiliki representasi poin komando yang diberikan untuk masyarakat pada era new normal. Hal 
KONSTRUKSI WACANA CITRA KEPEMIMPINAN JOKO WIDODO

DALAM PENANGANAN COVID-19 PADA INFOGRAFIS CNBC

INDONESIA

ini penting mengingat protokol

Langkah untuk menghadapi

kesehatan menjadi panduan utama

dampak Covid-19 diantaranya

untuk menjaga diri dari penularan

dilakukan dengan pemberian stimulus

Covid-19. Masyarakat harus mulai

pada masyarakat. Hal ini terlihat pada

terbiasa beraktivitas sehari-hari

infografis berjudul: "Ini 6 Paket

dengan protokol kesehatan. Meskipun

Bantuan Jokowi”. Paket bantuan

aktivitas masyarakat tak luput dari

Jokowi memberikan makna seolah-

ancaman penularan Covid-19.

Pandemi Covid-19 bukan hanya

menyerang sisi kesehatan masyarakat,

namun virus ini juga menyerang

ekonomi masyarakat. Oleh karena itu,

infografis berjudul "Arahan Presiden

RI Mengenai Percepatan Penanganan

Dampak Pandemi Covid-19” bukan

hanya untuk menuntaskan krisis

kesehatan semata namun juga krisis

ekonomi. Dampak ini yang

ditimbulkan dari penularan Covid-19, sehingga presiden juga perlu mengambil langkah untuk

meningkatkan kewaspadaan

masyarakat.
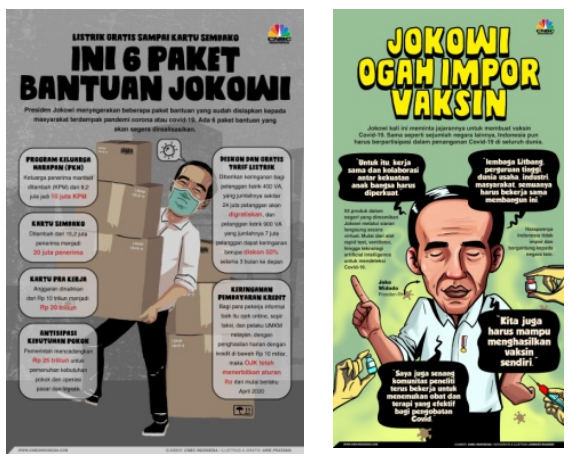

Gambar 7\&8. Infografis CNBC

Indonesia

Selain itu, pemerintah juga semakin memperketat langkah 
KONSTRUKSI WACANA CITRA KEPEMIMPINAN JOKO WIDODO

DALAM PENANGANAN COVID-19 PADA INFOGRAFIS CNBC

INDONESIA

kebijakan ekonominya. Diantaranya ilustrator netral, dan tidak memihak

dengan keengganan pemerintah kepada siapa pun.

melakukan impor vaksin. Hal ini

\section{Identitas}

tertuang dalam infografis "Jokowi

Aspek identitas melihat

Ogah Impor Vaksin". Sikap Joko

bagaimana identitas pembuat teks

Widodo tersebut turut menjadi sikap

ditampilkan dan dikonstruksi dalam

pemerintah secara menyeluruh. teks produksi. Norman Fairclough

Bahwa impor vaksin bukan menjadi juga melihat bagaimana pembuat teks

pilihan bagi pemerintah

tersebut menempatkan dan

\section{Relasi}

mengidentifikasi masalah atau

Unsur relasi yang ingin kelompok sosial yang terlibat.

ditunjukkan dalam delapan infografis Identitas ilustrator, tidak terkait

tersebut, yakni ilustrator ingin langsung dengan objek berita.

merekam dengan baik sikap Pasalnya, informasi dasar yang

pemerintah dan memberikan ilustrasi dijadikan bahan infografis berasal

yang mudah dipahami. Joko Widodo dari berita yang ditulis dalam website

digambarkan sebagai tokoh penting CNBCIndonesia.com. Ilustrator

pengambil kebijakan yang akan memilih isu-isu yang sedang ramai

menentukan nasib 270 juta penduduk dibicarakan dan menarik untuk

Indonesia. Joko Widodo juga dibuatkan grafisnya.

digambarkan seperti halnya manusia 2. Intertekstualitas

biasa yang juga merasakan kecewa. Pemilihan kata dalam judul

Apabila kinerja tidak sesuai dengan infografis dipengaruhi oleh judul

harapan. Dalam hal ini posisi utama yang terdapat dalam website 
KONSTRUKSI WACANA CITRA KEPEMIMPINAN JOKO WIDODO

DALAM PENANGANAN COVID-19 PADA INFOGRAFIS CNBC

INDONESIA

www.cnbcindonesia.com. Dimana

ada kesamaan pemilihan kata, yang terdapat pada judul infografis. Selain untuk mempertahankan konsistensi, kesamaan pilihan kata tersebut untuk menunjukkan penonjolan utama editorial redaksi terhadap suatu isu. Selain itu, pemilihan judul juga dilakukan dengan memilih diksi yang menarik.

"Infografis di CNBC Indonesia mengutamakan data. Belum tentu berita bagus, tapi gak didukung sama data, itu belum bisa dibuat infografis. Biasanya sumber data kami bisa dari berita di CNBC Indonesia dan website resmi institusi. Tugas infografer menyederhanakan data-data yang rumit, jadi lebih mudah dipahami. Di sini kita harus pikirkan konsepnya. Termasuk sosok presiden Joko Widodo, kami juga gambarkan secara lebih netral. Dalam satu hari, CNBC Indonesia bisa produksi minimal 3 infografis dari 3 infografer yang ada." (Arie Pratama, Infografer CNBC Indonesia)

Proses produksi dan pemilihan judul dipengaruhi oleh editor berita website. Ada bentuk upaya-upaya konvergensi media yang dilakukan oleh CNBC Indonesia. Sehingga produksi berita dapat linear terhadap isu yang sedang digarap. Selain itu, kesamaan judul juga dilakukan untuk menghindari adanya kesalahan persepsi berita.

Dalam konteks isu pemberitaan yang berkembang dalam infografis, disebutkan bahwa pemerintah tengah menghadapi kondisi yang berat dalam menghadapi pandemi Covid-19. Sehingga berbagai kebijakankebijakan luar biasa pun dijalani. Hal ini pun turut menuntut kerja ekstra bagi presiden dan jajarannya. Bila kerja yang dilakukan tidak sesuai dengan harapan, presiden pun akhirnya mengkritik para menteri. Hal ini tersaji dalam judul infografis Tak Cuma Sekali, Tapi Berkali-Kali Jokowi Jengkel Ke Menteri dan Jokowi Murka Ke Para Menteri.

Pada infografis Tak Cuma Sekali, Tapi Berkali-Kali Jokowi 
KONSTRUKSI WACANA CITRA KEPEMIMPINAN JOKO WIDODO

DALAM PENANGANAN COVID-19 PADA INFOGRAFIS CNBC

INDONESIA

Jengkel Ke Menteri juga disebutkan

alasan-alasan mengapa Joko Widodo

meluapkan amarahnya. Diantaranya

seperti tersaji pada poin keterangan:

permintaan pada menteri untuk lebih

peka terhadap kondisi ekonomi

karena diterpa Covid-19. Amarah

Joko Widodo juga timbul setelah dia

menerima laporan adanya sejumlah

industri yang mengeluh karena

kekurangan bahan baku, mulai dari

komoditas gula dan garam.

Permasalahan lain yang membuat

Joko Widodo kecewa antara lain

persoalan defisit transaksi berjalan

dan defisit neraca dagang yang tidak

pernah usai. Selain itu juga masalah

program tol laut yang melenceng dari

tujuan awal.

Di penghujung bulan Juni 2020,

Joko Widodo juga kembali marah.

CNBC Indonesia kembali merilis

infografis yang menunjukkan raut

wajah kemarahan Joko Widodo. Kali ini marahnya presiden lantaran para

menteri yang masih kerja biasa-biasa

saja. Padahal kondisi ekonomi dan

kesehatan akibat pandemi Covid-19

sudah cukup memprihatinkan.

Kutipan-kutipan marah yang

ditunjukkan Joko Widodo

ditampilkan dalam grafis. Pesan yang tersirat sangat jelas, untuk menunjukkan kemarahan presiden atas kinerja para menterinya. Bahkan kali ini, Joko Widodo sampai mengeluarkan ancaman reshuffle.

Kemarahan Joko Widodo juga turut diperkuat oleh gambaran kondisi ekonomi dan kesehatan warga Indonesia. Hal ini tersaji dalam infografis seperti Rupiah Tembus Di Atas 16.000, Gegara Covid-19, dan Bahan Pangan Indonesia Alami Defisit. Untuk menjawab kondisi tersebut, Joko Widodo juga mengambil langkah-langkah strategis. Diantaranya tersaji dalam infografis 
KONSTRUKSI WACANA CITRA KEPEMIMPINAN JOKO WIDODO

DALAM PENANGANAN COVID-19 PADA INFOGRAFIS CNBC

INDONESIA

berjudul Ini 6 Paket Bantuan Jokowi, isu lain menjadi saling

Jokowi Ogah Impor Vaksin, Lima bersinggungan. Produksi konten

Arahan Jokowi Adaptasi "New infografis dalam sehari kurang lebih

Normal", dan Arahan Presiden RI sebanyak 4 infografis.

Mengenai Percepatan Penanganan Dalam beberapa konten

Dampak Pandemi Covid-19. infografis, respons publik cenderung

3. Discource Practice beragam. Mulai yang positif hingga

Infografis diproduksi oleh yang bernada negatif. Memang media CNBC Indonesia. Dimana saat pemerintah memiliki keterbatasan ini, CNBC Indonesia memiliki jumlah untuk menyenangkan banyak pihak. follower instagram 340 ribu dan Sehingga muncul pula beberapa kritik follower di YouTube mencapai 933 terhadap kebijakannya. Misalnya ribu. Sementara dalam situs pengukur yang terdapat dalam infografis rating, Alexa, menempatkan CNBC berjudul Lima Arahan Jokowi Indonesia pada urutan ke-29 (per 17 Adaptasi "New Normal". Dalam Juli 2020). Pembaca maupun pemirsa artikel tersebut, melaui komentar di CNBC Indonesia menjadi modal instagram, publik justru menilai dasar untuk mengembangkan kualitas pemerintah tidak mampu mengatasi konten berita.

pandemi lewat penerapan pembatasan CNBC Indonesia berfokus pada sosial berskala besar (PSBB). produksi konten-konten ekonomi. Hal Sehingga pemerintah mengambil ini juga turut tersaji dalam konten jalan "new normal". Kritikan yang berita dalam infografis. Dimana isuisu ekonomi, yang juga terkait dengan berjudul Lima Arahan Jokowi 
KONSTRUKSI WACANA CITRA KEPEMIMPINAN JOKO WIDODO

DALAM PENANGANAN COVID-19 PADA INFOGRAFIS CNBC

INDONESIA

Adaptasi "New Normal".

\section{Sociocultural Practice}

Analisis sociocultural practice

didasarkan pada asumsi bahwa konteks sosial yang ada di luar media mempengaruhi bagaimana wacana yang muncul dalam media. Pada beberapa infografis, sosok Presiden Joko Widodo menjadi sentral dalam pemberitaan. Jabatan dan status yang diemban oleh Joko Widodo membuatnya menjadi orang nomer satu di Indonesia. Tak heran, setiap pernyataan maupun sikap Joko Widodo menjadi menarik untuk dicermati.

Hal ini juga tak terlepas dari budaya dan sistem sosial, bahwa pemimpin memiliki pengaruh untuk mengambil keputusan. Pemimpin sekaligus menjadi tokoh sentral yang mewakili populasi masyarakat. Sehingga tindakan presiden akan menentukan arah populasi masyarakat yang diwakilinya. Dalam sikapnya menghadapi pandemic Covid-19, Joko Widodo mengambil kebijakankebijakan yang sifatnya luar biasa (extraordinary). Hal inilah yang akhirnya dicermati oleh media.

\section{KESIMPULAN}

Berdasarkan kajian teoretis, penelusuran sumber data dan penelitian terdahulu, dapat disimpulkan teks berita memiliki konstruksi wacana terhadap suatu isu. Pemilihan kata maupun visualisasi data, memberikan pemaknaan dan wacana yang beragam. Salah satunya citra kepemipinan Joko Widodo selama menghadapi pandemi Covid19.

Sosok Joko Widodo menjadi tokoh sentral sebagai sumber pemberitaan media. Diantaranya melalui konten infografis CNBC Indonesia. Produksi pesan infografis, terintegrasi langsung dengan 
KONSTRUKSI WACANA CITRA KEPEMIMPINAN JOKO WIDODO

DALAM PENANGANAN COVID-19 PADA INFOGRAFIS CNBC

INDONESIA

pemberitaan di website

pandemi Covid-19. Langkah dan

CNBCIndonesia.com. Hal ini menjadi

langkah penyelarasan terhadap isu utama yang menjadi perhatian editorial.

Sebagai Presiden, Joko Widodo digambarkan memiliki sikap tegas dan berani mengambil tindakan. Terutama dalam mendorong kinerja para menteri. Joko Widodo juga digambarkan memiliki citra dermawan, dari infografis berjudul “Ini 6 Paket Bantuan Jokowi”. Meski pada kenyataannya, bantuan tersebut bersumber dari negara kepada rakyat. Joko Widodo hanya menjalankan amanah sebagai kepala negara.

Sebagaimana tersaji dalam teori analisis wacana kritis Norman Fairclough, citra kepemimpinan Joko Widodo dalam infografis digambarkan sebagai pemimpin negara yang mengambil tindakan penting sepanjang menghadapi sikap Joko Widodo digambarkan melalui pemilihan kata dan visualisasi gambar. Sehingga memperkuat pemaknaan pesan yang ingin disampaikan.

\section{DAFTAR PUSTAKA}

Annas, Akhirul dan Rana Akbari Fitriawan. 2018. Media dan Kekerasan: Analisis Norman Fairclough Terhadap Pemberitaan Tarung Gladiator. Jurnal Sospol 4(1): 37-54.

Baran, Stanley J. dan Dennis K. D. 1995. Mass Communication Theory: Foundations, Ferment, and Future 6th edition. Belmont: Wadsworth Pub. Co.

Bungin, Burhan. 2011. Penelitian Kualitatif: Komunikasi, Ekonomi, Kebijakan Publik, dan Ilmu Sosial Lainnya (2nd ed.). Jakarta: Kencana Prenadamedia Group.

CNBC Indonesia. 2020. Corona Bisa Bikin Resesi, Bursa Saham \& Minyak Dunia Crash. https://www.cnbcindonesia.com/m arket/20200312114605-17$\underline{144310 / \text { corona-bisa-bikin-resesi- }}$ bursa-saham-minyak-dunia-crash diakses pada Minggu, 12 Juli 2020 pukul 21.07 WIB. 
KONSTRUKSI WACANA CITRA KEPEMIMPINAN JOKO WIDODO

DALAM PENANGANAN COVID-19 PADA INFOGRAFIS CNBC

INDONESIA

CNBC Indonesia. 2020. Sindiran Jokowi:

Situasi Extraordinary, Prosedur

Kok

Berbelit.

https://www.cnbcindonesia.com/ne

ws/20200519095705-4-

159443/sindiran-jokowi-situasi-

extraordinary-prosedur-kok-

berbelit diakses pada Minggu, 12

Juli 2020 pukul 12.20 WIB.

Creswell, John W. 2010. Research Design, Pendekatan Kualitatif, Kuantitatif, dan Mixed.

Yogyakarta: Pustaka Pelajar.

Dur, B. I. U. 2014. Data visualization and infographics in visual communication design education at the age of information. Journal of Arts and Humanities, 3(5), 3950.

Eriyanto. 2012. Analisis Wacana : Pengantar Analisis Teks Media. Yogyakarta: LKiS Group.

Gasa, Frederik Masri. 2019. Analisis Wacana Kritis Norman Fairclough Pada Pernyataan Kontroversial Viktor Laiskodat. Jurnal Penelitian Ilmu-Ilmu Sosial 20(1), 8-14.

Haan, Yael de, dkk. 2017. When Does an Infographic Say More Than a Thousand Words? Journalism Studies. Hal. 1-20.

Halik, Abdul. 2013. Komunikasi Massa. Makassar: Alauddin University
Press.

Kurniasih, Nuning. 2016. Infografis. Prosiding Makalah Seminar Nasional: Komunikasi, Informasi dan Perpustakaan di Era Global, Hal 456-465.

Krum, R. 2013. Cool Infographics: Effective Communication with Data Visualization and Design. Indiana: John Wiley \& Sons, Inc.

Mulyana, Deddy dan Solatun. 2013.

Metode Penelitian Komunikasi:

Contoh- Contoh Penelitian

Kualitatif Dengan Pendekatan

Praktis. Bandung: Remaja

Rosdakarya.

Saptodewo, Febrianto. 2014. Desain Infografis Sebagai Penyajian Data Menarik. Jurnal Desain 1(3), 163218.

Wicandra, Obed Bima. (2006). Peran Infografis Pada Media Massa Cetak. Jurnal Nirmana 8(1), 44-50.

Yu, Xinyi dan Lei Shi. 2018. A Comparative Research on Cognitive Effect of Infographic and Animation Presentation in News. International Joint Conference on Information, Media and Engineering (ICIME). Wuhan. P. 73-76. 